\title{
Racial and ethnic diversity: Information exchange
}

\author{
By Susana Hinojosa \\ Chair, ACRL Racial and Ethnic \\ Diversity Committee
}

- The ACRL Racial \& Ethnic Diversity Committee's Coalition of Academic Librarians from Underrepresented Groups met for its first formal meeting at the ALA Conference in Atlanta on June 28,1991 . The meeting was very well attended by representatives from over 20 different groups plus a number of interested participants. Many ideas and suggestions regarding the future role of this coalition were enthusiastically discussed. The conclusion reached at the meeting was that for the immediate future the coalition could best serve as an information clearinghouse/exchange on events, programs, studies, etc., within ALA that are of interest to the targeted groups. It was suggested that this exchange of information could result in better communication, possible cosponsorship of programs and events, better coordination of similar programs, and joint work on projects. One specific recommendation that received strong support concermed the establishment of an electronic bulletin board to be devoted to multicultural issues in libraries. The recommendation is now being studied. The coalition under the guidance of Gladys Chaw will work on the above projects. Please forward comments and information to: Gladys Chaw, Library, College of San Mateo, 1700 W. Hillsdale Blvd., San Mateo, CA 94402.

- Penfield Library, State University of New York College at Oswego, forwards an interesting packet of information describing its Library Reference Assistants (LRA) Program. Created in response to concerns that library staff were not reaching the minority students on campus, the LRA Programparticipants are minority and nontraditional students. Trained and scheduled at the Library's Information Desk during the busiest hours, the LRAs help students use the library. The packet includes: a description of the program and participants; training/ibrary instruction sessions; a selected bibliography; a publicity leaflet; and LRA statement of responsibilities. Contact: Nancy Osborne, Specialized Instructional Services, Penfield Library, State University of New York, College at Oswego, Oswego, NY 13126.

- "Difficult Dialogues: Achieving the Promise in Diversity" was the theme for the National Con- ference on Higher Education sponsored by the American Association for Higher Education, in Washington, D.C., in mid-March 1991. Highlights included: keynote speaker Dr. Johnetta Cole, president, Spelman College; Toni Morrison, Tomas Rivera Lecture entitled "Education and Anger"; and Elie Wiesel, Nobel laureate, on "Education Against Hatred." There were approximately 1800 participants with about 25 library professionals attending. Em Claire Knowles, assistant dean, Graduate School of Library and Information Science, Simmons College, attended this conference and reports that, "There is much research that relates to racial and ethnic diversity from which academic libraries can benefit...." All of the plenary sessions and many of the other conference sessions were audiotaped and can be purchased from $\mathrm{AAHE}$ Headquarters, One Dupont Circle, Suite 600, Washington, DC 20036-1110. The 1992 National Conference on Higher Education is scheduled to be held April 5-8, 1992, in Chicago.

- The California Library Association, California Society of Librarians (CLA CSL) Library School Recruitment Committee is currently coordinating many of its recruitment activities with the Northern California Library Schools Recruitment Committee. Plans currently are underway to ensure that librarianship is represented at the Graduate School Days scheduled at University of California and California State Universities campuses during October and November 1991. Librarians will be present at many of these events to represent the California library schools. A special focus of this recruitment is to reach and recruit minority students interested in graduate schools into librarianship and information science. To date, librarians will be present at approximately eight campuses throughout California. Recruitment materials include: brochures and catalogs from the three California library schools; materials developed by the schools describing typical coursework, etc.; and financial aid information from ALA and the California State Library. Contact Susana Hinojosa, Moffitt Undergraduate Library, University of California-Berkeley, Berkeley, CA 94720 for more information and lists of materials. 